\title{
Allergy as an epithelial barrier disease
}

\author{
Pirkko Mattila, Sakari Joenväärä, Jutta Renkonen, Sanna Toppila-Salmi and Risto Renkonen*
}

\begin{abstract}
The objective of this review is to focus on putative modified epithelial functions related to allergy. The dysregulation of the epithelial barrier might result in the allergen uptake, which could be the primary defect in the pathogenesis of allergic reaction. We review the literature of the role of respiratory epithelium as an active barrier, how allergens are transported through it and how it senses the hostile environmental allergens and other dangerous stimuli.
\end{abstract}

\section{Introduction}

Acute allergic reactions are known to be symptomatic type-I hypersensitivity responses caused by an allergen cross-linking specifically with anti-IgE molecules on the surface of pre-sensitized mast cells [1-4]. In Europe the incidence of allergies rapidly increasing and thus we are facing an epidemic outburst of these diseases [5]. Even though costs per a patient are usually small allergies cause a major economical burden to the society, since up to $20 \%$ of the population now suffers from these disorders for instance in Finland [6]. Because of this the Finnish authorities have launched an "Allergy project 2008-2018", where a new direction has been taken. Here the patients will now be tolerated towards the antigens instead of avoiding them [6].

Currently there are two, partially different basic theories on the pathogenesis of allergy. For decades the primary assumption has been that allergy is caused by unbalanced and overactive immunological responses against allergens, mostly driven by activated Th2 cells and due to aberrant $\mathrm{T}$ - regulatory cells. The second more recent hypothesis relies on the dysregulation of the epithelial barrier, which might result in the allergen uptake as a primary defect in the pathogenesis of allergic reactions. There is a wealth of literature on $\mathrm{T}$ cell responses in allergic diseases $[7,8]$, and thus the objective of this review is to focus on putative modified epithelial functions related to allergy [9-11].

\footnotetext{
* Correspondence: risto.renkonen@helsinki.fi
Transplantation Laboratory \& Infection Biology Research Program, Haartman

* Correspondence: risto.renkonen@helsinki.fi
Transplantation Laboratory \& Infection Biology Research Program, Haartman Institute, University of Helsinki \& Helsinki University Central Hospital, HUSLAB, Helsinki, Finland
}

(c) 2011 Mattila et al; licensee BioMed Central Ltd. This is an Open Access article distributed under the terms of the Creative Commons Attribution License (http://creativecommons.org/licenses/by/2.0), which permits unrestricted use, distribution, and reproduction in any medium, provided the original work is properly cited.

Epithelium as an active barrier

Respiratory epithelium is the first barrier to the external environment and thus crucially important in the protection of the internal environment. Normally three independent and complex networks connect epithelial cells to each other; desmosomes, adherens junctions, and tight junctions [12]. The respiratory epithelium senses changes in its local environment such as the allergen exposure and also actively responds to these changes $[13,14]$.

Interleukin (IL)-25, IL-33, and thymic stromal lymphopoietin (TSLP) are cytokines, which have a role in Th2-type allergic responses [15]. Previously the epithelium was considered only as a barrier, but now it is considered as a central player in controlling the immune function release of innate cytokines-promoting Th2 responses and the activation of local dendritic cells [16-18]. The exposure of airways to aeroallergens induces a rapid release of these three cytokines from the epithelial cells into the airway lumen and initiates an allergic immune response $[19,20]$.

Recently, disruption in the epithelial barrier has been included into the primary defects in allergic diseases. Atopic dermatitis (i.e. atopic eczema) is an allergic disease characterized by the defective epidermal barrier function, immunological dysregulation, and IgEmediated sensitization to pollen allergens and food $[21,22]$. Loss-of-function mutations in the filaggrin gene are linked to atopic dermatitis and other related diseases including peanut allergy [22]. Filaggrin dysfunction has been suspected to cause the impaired barrier function in the skin allowing the allergen penetration and followed by a local inflammation. To more directly verify the link between mutated filaggrin and the barrier dysfunction 
an elegant survey with wasp allergies was conducted. Wasp stings bypass the skin surface and antigen is injected deep into the dermis [21]. Patients with atopic dermatitis have an increased frequency of the most common filaggrin null mutations (R501X and 2282del4) compared to those with wasp allergy and healthy subjects. This data supports the role of mutated filaggrin in the epithelial dysfunction resulting in the allergic sensitization [21].

The respiratory epithelium is constantly facing hostile injurious stimuli causing damage. Proliferation and differentiation of resident progenitor and stem cells repair the damages and try to maintain the protective barrier [23]. The concept of unified airways suggests that in addition to the anatomic continuity, also inflammation influences the homeostasis of other parts of the airway [24-26]. In vivo challenge with the birch pollen allergen, Bet $\mathrm{v}$ 1, leads to instant leukocyte extravasation into conjunctival and nasal mucosa only in patients allergic to birch pollen, but not in healthy subjects.

\section{Allergen transport through the epithelium}

Several of the known allergens are proteases [27,28]. Impaired epithelial barrier function can be a direct consequence of proteolytic activity of inhaled allergens, including house dust mite (HDM) [29]. After causing injury to the epithelium Der p $1 \mathrm{~m}$, the major allergen in HDM, can enter the tissue and induce mediate inflammation via Toll-like receptor 4 (TLR4) [30,31]. Der p 2, another allergen from HDM activates respiratory epithelial cells, indicating that this non-proteolytic allergen, in addition to its immunogenic properties, can aggravate a respiratory airway disease by an adjuvant [32].

Also toxic perturbations such as exposure to cigarette smoke can induce epithelial cell gaps and a decrease in trans-epithelial resistance [33]. Cigarette smoke exposure induces also a significant increase in the allergen uptake to epithelium. Thus smoking reduced the barrier function of the respiratory epithelium for allergens and contributed to exacerbation of an allergic disease [33].

A new concept is to focus on the aberrant innate responses of the respiratory epithelium to viral or bacterial infections and how these responses may increase the risk of allergic diseases [34]. As novel sequencing techniques are emerging the role of the resident respiratory microbiome and its influence on the local immune response can now be studied more efficiently $[35,36]$.

The very rapid increase in the incidence of allergic diseases over the last 30 years and the differences in the prevalence of an allergic disease between industrialized and developing countries both suggest that something else than variations in human genetics is the cause of this allergic epidemic $[5,6,37]$. These observations led to the generation of the "hygiene hypothesis", i. e, the lack of an early microbial stimulation or an exposure to soil and dirt results in dysregulated immune responses to allergens later in life $[6,38]$. The respiratory epithelium is the home to microbiome, which is estimated to be composed of $10 \times 10^{12}$ microbes, with a diversity of greater than 1,000 species within each individual [39]. The international Human Microbiome Project aims to define the human microbiome from various locations within the body both in health and in various diseases $[40,41]$. Several different combinations of local microbes can contribute to the local environment and thus alter the barrier functions of the respiratory epithelium.

Allergen-containing subpollen particles from timothy grass were shown to first bind to and then be internalized by primary epithelial cells in a dose dependent manner. The binding was enhanced with the surfactant protein -D and coincided with the secretion of Interleukin (IL)-8 [42]. Timothy grass pollen allergen Phl p 1 activated respiratory epithelial cells by a non-protease mechanism [43]. Enhancement of TGF-beta, IL-6 and IL- 8 induced by Phl p 1 might provide an indirect mechanism through which the allergen may cross the epithelial barrier. Furthermore, recent observations also indicated that timothy grass allergen $\mathrm{Phl} \mathrm{p} 1$ is actively transported though the epithelium [44].

Already one minute in vivo challenge with birch pollen caused Bet v 1 binding to conjunctival epithelial surfaces in the allergic, but not in the healthy individuals

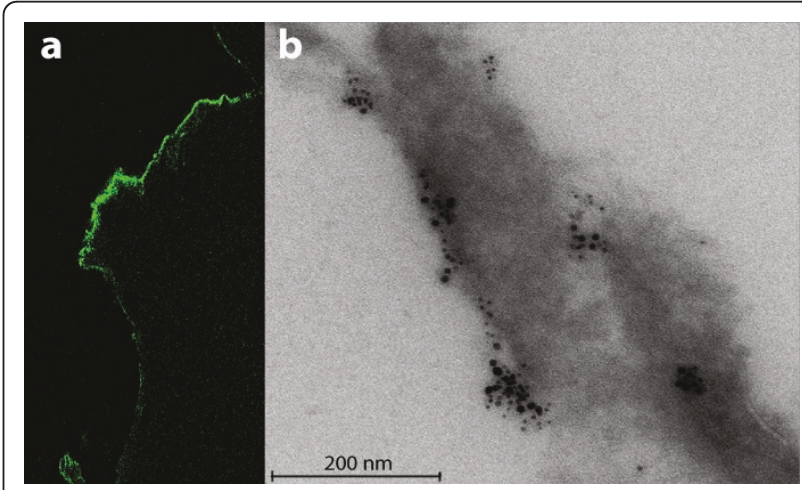

Figure 1 Bet $v 1$ binds to and is transported through the conjunctival epithelium only in allergic, but not in healthy subjects. Panel a; A conjunctival epithelial biopsy taken from an allergic patient $1 \mathrm{~min}$ after the in vivo birch pollen challenge indicated a clear Bet $\vee 1$ location detected with anti- Bet $\vee 1$ antibodies (green staining for Bet $\vee$ 1). Original magnification $\times 200$. Panel b; The strong clustered staining of anti-Bet $\vee 1$ detected with gold label particles at the epithelial villus. Bet $\vee 1$ was seen to colocalise with caveolin 2 as shown with double immunoTEM using an anti- Bet $\vee 110 \mathrm{~nm}$ gold-labelled antibody and anti-caveolin 25 $\mathrm{nm}$ gold-labelled antibody, magnification $\times 27$ 500. Bet $\vee 1$ was almost solely (75\%) co-localised with a caveolar marker protein caveolin 2. 
(Figure 1a) [45]. Bet v 1 entry into the epithelium was evident also in immuno transmission electron microscopy (TEM) in the allergic, but not in the healthy individuals. One minute after the birch pollen perturbation, before the fulminant clinical symptoms, Bet $\mathrm{v} 1$ was found both on the cell surfaces of villae as well as within the villae, in the cytoplasm, in intracellular vesicles, and also in the nuclei of epithelial cells in allergic patients [45]. At the same time there was no Bet v 1 in the conjunctival epithelial cells of the healthy subjects (Cell level, Table 1). In conjunctival biopsies anti-Bet $\mathrm{v} 1$ staining was seen dispersed into the more basal epithelial cell layers (Tissue level, Table 1). These observations support a very rapid traffic through the epithelium in allergic patients, but not in healthy subjects. Currently the putative receptor(s) mediating this allergen binding and facilitating its transport through the epithelium is not known. A striking specificity is observed when birch pollen allergic subjects were also challenged with timothy grass pollen and no entry of this pollen allergen Phl p 1 into epithelial cells was detected ( $R$. Renkonen unpublished data). While the specific transport mechanism for birch pollen remains unsolved the first hints of the role of caveolae in this have been obtained. In the double immunoTEM stainings caveolin 2, but not caveolin 1 or 3 , was present on the conjunctival epithelial surface in the same clusters as Bet v 1 (Figure 1). A great majority of anti-Bet $\mathrm{v} 1$ staining in the epithelial cells was colocalized also with another caveolar marker, flotillin 2. Thus the observed Bet v 1 traffic could involve an active lipid raft and caveolar-dependent transport [46].

While the above data suggests a caveolar-dependent traffic, the primary contact with the epithelium is still unknown. Small proteins like cholera toxin or much larger cargo like full Pseudomonas bacteria can be transported to and through epithelial cells via lipid raft and

Table 1 Bet $\mathbf{v} 1$ distribution in the epithelial cells and tissues in allergic patients

\begin{tabular}{lll}
\hline & & Distribution of Bet $\mathbf{v ~} \mathbf{1}$ \\
\hline Cell level & On the surfaces of villi & $18 \%$ \\
\hline & Within villi & $11 \%$ \\
\hline & Within cytoplasm & $51 \%$ \\
\hline Within vesicles & $17 \%$ \\
\hline & Within nuclei & $3 \%$ \\
\hline On the apical surface & $7 \%$ \\
\hline & Epithelial cell layer 1 & $29 \%$ \\
\hline & Epithelial cell layer 2 & $26 \%$ \\
\hline & Epithelial cell layer 3 & $22 \%$ \\
\hline & Epithelial cell layer 4 & $16 \%$ \\
\hline
\end{tabular}

Note that the epithelium of healthy patients neither bound nor transported the Bet $v 1$ allergen. caveolar mechanisms [47]. In the gastrointestinal tract food proteins are the targets for lysosomal degradation while selective food allergens are protected from this when they are transported across the intestinal epithelium by their binding to cell surface IgE/CD23 (FceRII) complexes. The presence of IgE/CD23 on the intestinal epithelium provides means for intact transcytosis for food allergens across the epithelium, and this can lead to classical mast cell-dependent type I anaphylactic allergic reactions [48]. So far this direct interaction with $\mathrm{IgE}$ and its low affinity receptor CD23 has been detected only in the intestinal but not in the respiratory epithelium. However, as the transport of pollen allergens through the respiratory epithelium seems to be specific, e.g., our patients allergic to birch pollen do not transport timothy grass allergen and vice versa, it is most likely antibody-dependent. Some other allergens are actively and specifically transported through the respiratory epithelium. Ovalbumin allergen (OVA) is taken up rapidly via the respiratory epithelium both in the nose and lower airways in a rodent model [49]. Also, human respiratory epithelial cells internalize timothy grass pollen allergen, Phl p 1 [44].

\section{Bet v 1 associated epithelial caveolar proteins}

Microscopy provided evidence for the novel hypothesis of active allergen transport. This led us to clarify whether the Bet $\mathrm{v}$ 1-associated epithelial proteins act as putative receptors in this intraepithelial traffic. With the help the covalently matrix-bound Bet v 1 antigen and nasal epithelial protein lysates collected from both healthy and allergic subjects we began to identify these interacting proteins. By extensive analyses applying both database-related and de novo identifications we generated a shortlist of Bet $\mathrm{v}$ 1-binding epithelial proteins found only in the allergic patients. Six out of these sixteen proteins (40\%) had previously been identified as caveolar proteins: ACTG, ANXA2, CALM, KCNA5, PLEC1, STML2 (Table 2, [46]). While the entire human proteome consists of less than $1 \%$ of caveolar proteins, the Bet $\mathrm{v} 1$ associated list of proteins was highly enriched with the caveolar proteins. This observation provided independent support for the observation that Bet $\mathrm{v} 1$ could be transported actively through the epithelium within caveolae at the onset of an allergic reaction.

\section{Bet v 1 associated epithelial caveolar lipids}

The primary contact between the allergen and the epithelium can be mediated by lipids. Bet $\mathrm{v} 1$ has been shown to bind cholesterol and enter the epithelium of allergic patients in cholesterol- and glycolipid-rich caveolae [50-52]. We performed 3-D modeling of Bet $\mathrm{v}$ 1 and its possible lipid ligands. We modeled a large 
Table 2 Bet v 1-associated nasal epithelial proteins found in the allergic, but not in the healthy subjects

\begin{tabular}{|c|c|}
\hline \multicolumn{2}{|c|}{$\begin{array}{l}\text { Proteins found in caveolae and lipid } \\
\text { rafts. }\end{array}$} \\
\hline Name & Functions \\
\hline ACTG, gamma actin & A subunit of microfilaments, one of the three major components of the cytoskeleton \\
\hline ANXA2, Annexin 2 & Belongs calcium-binding proteins, suppresses phospholipase A2 and thus inhibits inflammation. \\
\hline CALM, Calmodulin & Belongs calcium-binding proteins, regulation of nuclear transport. \\
\hline KCNA5 & Voltage-dependent potassium ion permeability, has a role in regulating the secretion of insulin \\
\hline PLEC1, Plectin & Intermediate filament binding protein \\
\hline STML2, Stomatin 2 & Colocalized at intercellular junctions and regulated gap junctions and lipid domain organization. \\
\hline \multicolumn{2}{|l|}{ Other epithelial proteins } \\
\hline Name & Functions \\
\hline CROCC, Ciliary rootlet & A cytoskeletal-like structure in ciliated cells \\
\hline DCD, Dermcidin & $\begin{array}{l}\text { Displays antimicrobial activity thus limiting infection by potential pathogens, such as E.coli and S. } \\
\text { aureus. }\end{array}$ \\
\hline$\overline{\mathrm{ECHB}}$ & Participates in lipid metabolism. \\
\hline EPIPL, Epiplakin & A cytoskeletal linker protein, interactions between epiplakin and intermediate filaments \\
\hline GNDS, Ral/RalBP1 & Plays a role in endocytosis and vesicle sorting and migration. \\
\hline K1C18, Cytokeratin 18 & A subunit of intermediate filament, one of the three major components of the cytoskeleton \\
\hline MARCO & $\begin{array}{l}\text { Scavenger receptor, a major mediator of non-opsonized E. coli phagocytosis clearance of bacteria in } \\
\text { vivo }\end{array}$ \\
\hline MYCB2 & Mediates ubiquitination and subsequent proteasomal degradation of target proteins \\
\hline $\mathrm{S100P}$ & Overexpressed in epithelium in psoriasis, wound healing, skin cancer, inflammation, calcium-binding \\
\hline TBA8, Alpha-tubulin & The major constituent of microtubules, one of the three major components of the cytoskeleton. \\
\hline
\end{tabular}

group of putative lipid ligands for Bet $\mathrm{v} 1$ on the atomic level with a computational ligand docking using the CDOCKER algorithm, which is based on the CHARMm force field engine [53].

We conducted 3-D docking with both experimentally verified Bet v 1 ligands as well as with larger lipid molecules for which experimental affinity studies were not available. In silico data suggested that Bet $\mathrm{v} 1$ can bind also to more complex amphiphilic molecules like ceramides, sphingomyelins and even glycolipids, all of which are present on lipid rafts and caveolar surfaces [53]. Thus a binding model was drafted, where the hydrophobic tail groups of lipids are located in the central Yshaped cavity of the Bet v 1 molecule, while the polar head group points out from the molecule. Taken together, these data provide a hypothesis on how Bet $\mathrm{v}$ 1 could directly interact with epithelial surface lipids [53]. It remains to be verified experimentally whether any of these lipids actually participate in the birch pollen uptake on the epithelial surfaces during the early phases of allergic reactions.

\section{Allergen induced responses on the epithelium}

A hypothesis-free approach in order to analyze the differences between respiratory epithelial swabs from allergic and healthy subjects during the asymptomatic winter period [45,46,54], 182 significantly differentially expressed transcripts (and thus proteins after converting them to corresponding proteins) in between these two groups could be detected. Twenty-two epithelial cell surface receptors displayed enhanced expression levels in allergic compared to healthy subjects and eight out of them were found in lipid rafts/caveolae according to manual PubMed literature search (Table 3, [45]). The kinetics of the Bet $\mathrm{v} 1$ caveolar traffic resembles in many ways other previously known caveolar-dependent phenomena, such as the entry of bacterial toxins, whole viruses, bacteria or even parasites [55-61].

In another approach the response of epithelium to the birch pollen challenge was analyzed. Nasal epithelial cell swabs were collected from both allergic and healthy subjects in winter (no symptoms) and during the birch pollen season in May when allergic patients suffer from clinical symptoms. The allergic subjects displayed 331 transcripts between these two time points [46]. Surprisingly the healthy subjects displayed a much stronger response, while they remained without any clinical symptoms through the experiment. Out of the 605 transcripts recorded as altered in healthy controls, the Gene Ontology (GO) category Immune response was the most significantly upregulated. This immune response was not present in allergic subjects giving us the first 
Table 3 Membrane-bound receptors associated with lipid raft and/or caveolae and displaying upregulated transcript expression levels in allergic compared to healthy conjunctival specimens

\begin{tabular}{|c|c|}
\hline $\begin{array}{l}\text { ARBK1, } \\
\text { Beta-adrenergic receptor kinase } 1\end{array}$ & $\begin{array}{l}\text { Specifically phosphorylates the agonist-occupied form of the beta-adrenergic and closely related } \\
\text { receptors. }\end{array}$ \\
\hline $\begin{array}{l}\text { CD59, } \\
\text { CD59 glycoprotein }\end{array}$ & $\begin{array}{l}\text { Potent inhibitor of the complement membrane attack complex (MAC) action. Involved in signal } \\
\text { transduction for T-cell activation complexed to a protein tyrosine kinase. }\end{array}$ \\
\hline $\begin{array}{l}\text { EFNB3, } \\
\text { Ephrin-B3 }\end{array}$ & $\begin{array}{l}\text { May play a pivotal role in forebrain function. Binds to, and induces the collapse of, commissural } \\
\text { axons/growth cones in vitro. }\end{array}$ \\
\hline $\begin{array}{l}\text { EPHA1, } \\
\text { Ephrin type-A receptor } 1\end{array}$ & Receptor for members of the ephrin-A family. Binds with a low affinity to ephrin-A1 \\
\hline $\begin{array}{l}\text { P2RY4, } \\
\text { P2Y purinoceptor } 4\end{array}$ & $\begin{array}{l}\text { Receptor for UTP and UDP coupled to G-proteins that activate a phosphatidylinositol-calcium second } \\
\text { messenger system. }\end{array}$ \\
\hline $\begin{array}{l}\text { SSR4, } \\
\text { Somatostatin receptor type } 4\end{array}$ & The activity of this receptor is mediated by G proteins, which inhibit adenylyl cyclase. \\
\hline $\begin{array}{l}\text { TNFL8, } \\
\text { Tumor necrosis factor ligand superfamily } \\
\text { member } 8\end{array}$ & Cytokine that binds to TNFRSF8/CD30. Induces proliferation of T-cells. \\
\hline $\begin{array}{l}\text { TRPA1, } \\
\text { Transient receptor potential cation channel } \\
\text { subfamily A member } 1\end{array}$ & $\begin{array}{l}\text { Has a central role in the pain response to endogenous inflammatory mediators and to a diverse } \\
\text { array of volatile irritants, such as mustard oil, garlic and capsaicin. }\end{array}$ \\
\hline
\end{tabular}

A short characterization from SwissProt is included.

hint to that allergy might be, at least partially, caused by lack of protective immune defense at the epithelial surfaces [46]. These results suggest that to truly learn about the pathogenesis of diseases one must analyze also how the healthy subjects respond.

A precise time-series analysis was performed with allergic patients and healthy control subjects. The first nasal epithelial specimens were obtained in February when all subjects were symptom-free and the following four nasal epithelial cell swabs were collected from each subject at weekly intervals starting in mid-April when the birch pollen season in Finland begins. While the healthy subjects remained totally symptomless throughout this whole period of time the allergic subjects began to have symptoms already in April, which worsened along with the birch pollen season [54].

Patients allergic to birch pollen showed 105 uniquely regulated nasal epithelial transcripts (converted to proteins for further analyses) with increasing clinical symptoms. Dyneins were among the most enriched Gene Ontology (GO) categories in the list of proteins. Dyneins are molecular motors for the epithelial intracellular caveolar cargo traffic along the microtubuli and ciliary movements [54].

The epithelial cells collected from healthy subjects displayed 22 unique and significantly altered transcripts during the birch pollen season when compared to the winter season. Forty percent of these uniquely regulated genes, i.e., CXCL6, CXCL9, CXCR2, CXL10, FPR1, IL1 and IL8, NKG7, and PGSG belonged to the Gene Ontology category Immune response (GO:0006955). This Immune response category contains altogether only few percent of all annotated proteins of the human proteome (amigo.geneontology.org). Thus the birch pollen allergen induced a strong epithelial immune response in healthy subjects, while this response was lacking from the epithelium of allergic patients [54]. It is remarkable that a similar immunoresponse has been documented on primary human nasal epithelial cells isolated form healthy subjects after HMD challenge and that this response is lacking from the epithelium of allergic subjects. Here also the number of modified transcripts was significantly larger in healthy epithelium that in the allergic (555 compared to 301 probe sets). Many transcripts remain unaffected by the HDM-exposure in the allergic epithelium while these same transcripts were modified by HDM in the healthy epithelium. Genes involved in immunoresponse and with this expression pattern are: IL-1b, IL-8, CXCL2, CXCL3, CCL20, CTGF, HBEGF, and AREG $[14,62,63]$.

How does the epithelium detect danger and respond to it? There are extensive recent reviews on the topic $[14,64]$. In short the respiratory epithelium continuously senses the changes in its environment. There are several families of receptors to carry out this including eleven human Toll-like receptors (TLR1-11). They are all membrane bound receptors which mediate effects through dimerization and complex downstream signaling [65]. Other receptors involved in the initiation of epithelial innate immunity include the families protease-activated receptors (PAR1-4), NOD and leucine-rich repeats containing receptors (NLRs) including NOD1 and NOD2 [14,64]. Although a great number of research data has been published on this field with a special reference to the anti microbial defense the true role of this arm on immunology in the development of allergies and asthma remains to be solved $[66,67]$. 


\section{Conclusions}

Could allergy be either a epithelial disease or a disease of the immune system? So far it seems that both answers are correct. There is a wealth of immunological studies indicating an altered regulation of IgE production, Th2-response, and other hyperimmune responses, which we do not discuss further in this Review. The role of the epithelial barrier function in allergies has recently also been identified. Filaggrin mutations have been identified constantly in atopic dermatitis and this provoked increasing interest in studies trying to identify the epithelial barrier dysfunction in allergic diseases $[68,69]$. It is also interesting that mutations in the filaggrin gene not only cause atopic dermatitis, but also lead to a significantly increased risk for other allergic diseases and asthma in the context of eczema [70]. The defective airway epithelial barrier functions together with disrupted tight junctions and innate immunity are also encountered in asthma patients. This could explain the significant impact of viruses and bacteria in acute asthma exacerbations [71,72]. The expensive genome-wide association (GWA) studies have yielded several hypothesisfree candidate genes with known or suspected links to epithelial barrier functions for further analyses in allergic diseases $[73,74]$. Finally novel approaches pursuing to measure epithelial proteomics [75] and lipidomics [76] will become possible in near future thus allowing us to broaden the DNA and mRNA based GWA analyses.

Taken together, new data has been generated on the role of modified epithelial barrier functions in the early phases of allergic diseases. Active transport of allergens through the epithelium might be incorporated to the pathogenesis of allergy. It is possible that the healthy epithelium displays a strong immune response against pollen allergens and thus escapes from becoming allergic. This challenges the concept of hypersensitivity as the only driving force behind allergic reactions. In fact, if allergy turns out to be, at least in part, a result of epithelial hyposensitivity, it could have major consequences in the strategies of prevention and treatment of these diseases. Towards this end, a national allergy program was launched in Finland in 2008, which changes the basic idea of trying to avoid allergens to the concept of natural exposure and tolerance [6].

\footnotetext{
Acknowledgements

The original work in the Renkonen laboratory referred here was supported in part by research grants from Academy of Finland, Sigrid Juselius Foundation, and Helsinki University Central Hospital Research Funds.
}

Authors' contributions

All authors drafted and approved the final manuscript.

\section{Competing interests}

The authors declare that they have no competing interests.

Received: 11 March 2011 Accepted: 10 June 2011

Published: 10 June 2011

\section{References}

1. Bohle B: The impact of pollen-related food allergens on pollen allergy. Allergy 2007, 62:3-10.

2. D'Amato G, Cecchi L, Bonini S, Nunes C, Annesi-Maesano I, Behrendt H, Liccardi G, Popov T, van Cauwenberge P: Allergenic pollen and pollen allergy in Europe. Allergy 2007, 62:976-990.

3. Larche $M$, Akdis CA, Valenta R: Immunological mechanisms of allergenspecific immunotherapy. Nat Rev Immunol 2006, 6:761-771.

4. Ring J, Grosber M, Mohrenschlager M, Brockow K: Anaphylaxis: acute treatment and management. Chem Immunol Allergy 2010, 95:201-210.

5. Bousquet J, Burney PG, Zuberbier T, Cauwenberge PV, Akdis CA, BindslevJensen C, Bonini S, Fokkens WJ, Kauffmann F, Kowalski ML, LodrupCarlsen K, Mullol J, Nizankowska-Mogilnicka E, Papadopoulos N, Toskala E, Wickman M, Anto J, Auvergne N, Bachert C, Bousquet PJ, Brunekreef B, Canonica GW, Carlsen KH, Gjomarkaj M, Haahtela T, Howarth P, Lenzen G, Lotvall J, Radon K, Ring J, et al: GA2LEN (Global Allergy and Asthma European Network) addresses the allergy and asthma 'epidemic'. Allergy 2009, 64:969-977.

6. Haahtela T, von Hertzen L, Makela M, Hannuksela M: Finnish Allergy Programme 2008-2018-time to act and change the course. Allergy 2008, 63:634-645.

7. Palomares O, Yaman G, Azkur AK, Akkoc T, Akdis M, Akdis CA: Role of Treg in immune regulation of allergic diseases. Eur J Immunol 2010, 40:1232-1240.

8. Ray A, Khare A, Krishnamoorthy N, Qi Z, Ray P: Regulatory T cells in many flavors control asthma. Mucosal Immunol 2010, 3:216-229.

9. Davies DE: The role of the epithelium in airway remodeling in asthma. Proc Am Thorac Soc 2009, 6:678-682.

10. Holgate ST: Has the time come to rethink the pathogenesis of asthma? Curr Opin Allergy Clin Immunol 2010, 10:48-53.

11. Schleimer RP, Kato A, Peters A, Conley D, Kim J, Liu MC, Harris KE, Kuperman DA, Chandra R, Favoreto S Jr, Avila PC, Grammer LC, Kern RC: Epithelium, inflammation, and immunity in the upper airways of humans: studies in chronic rhinosinusitis. Proc Am Thorac Soc 2009, 6:288-294.

12. Groschwitz KR, Hogan SP: Intestinal barrier function: molecular regulation and disease pathogenesis. J Allergy Clin Immunol 2009, 124:3-20, quiz 2122.

13. Kouzaki H, lijima K, Kobayashi T, O'Grady SM, Kita H: The Danger Signal, Extracellular ATP, Is a Sensor for an Airborne Allergen and Triggers IL-33 Release and Innate Th2-Type Responses. J Immunol 2011, 186:4375-4387.

14. Vroling $A B$, Fokkens WJ, van Drunen CM: How epithelial cells detect danger: aiding the immune response. Allergy 2008, 63:1110-1123.

15. Comeau MR, Ziegler SF: The influence of TSLP on the allergic response. Mucosal Immunol 2010, 3:138-147.

16. Bulek K, Swaidani S, Aronica M, Li X: Epithelium: the interplay between innate and Th2 immunity. Immunol Cell Biol 2010, 88:257-268.

17. Godoy L: Allergic inflammation: where epithelial function interacts with immune response in atopic diseases. Drug News Perspect 2009, 22:233-236.

18. Hammad H, Lambrecht BN: Dendritic cells and airway epithelial cells at the interface between innate and adaptive immune responses. Allergy 2011, 66:579-587.

19. Broide DH: Allergic rhinitis: Pathophysiology. Allergy Asthma Proc 2010, 31:370-374.

20. Turvey SE, Broide DH: Innate immunity. J Allergy Clin Immunol 2010, 125: S24-32.

21. Aslam A, Lloyd-Lavery A, Warrell DA, Misbah S, Ogg GS: Common filaggrin null alleles are not associated with hymenoptera venom allergy in europeans. Int Arch Allergy Immunol 2011, 154:353-355.

22. Brown SJ, Asai Y, Cordell HJ, Campbell LE, Zhao Y, Liao H, Northstone K, Henderson J, Alizadehfar R, Ben-Shoshan M, Morgan K, Roberts G, Masthoff L, Pasmans SG, van den Akker PC, Wijmenga C, Hourihane JO, Palmer CN, Lack G, Clarke A, Hull PR, Irvine AD, McLean WH: Loss-of- 
function variants in the filaggrin gene are a significant risk factor for peanut allergy. J Allergy Clin Immunol 2011, 127:661-667.

23. Zheng $\mathrm{T}, \mathrm{Yu}$ J, Oh MH, Zhu Z: The atopic march: progression from atopic dermatitis to allergic rhinitis and asthma. Allergy Asthma Immunol Res 2011, 3:67-73

24. Compalati E, Ridolo E, Passalacqua G, Braido F, Villa E, Canonica GW: The link between allergic rhinitis and asthma: the united airways disease. Expert Rev Clin Immunol 2010, 6:413-423.

25. Guilemany JM, Angrill J, Alobid I, Centellas S, Pujols L, Bartra J, BernalSprekelsen M, Valero A, Picado C, Mullol J: United airways again: high prevalence of rhinosinusitis and nasal polyps in bronchiectasis. Allergy 2009, 64:790-797.

26. Hellings PW, Prokopakis EP: Global airway disease beyond allergy. Curr Allergy Asthma Rep 2010, 10:143-149.

27. Jacquet $A$ : Interactions of airway epithelium with protease allergens in the allergic response. Clin Exp Allergy 2011, 41:305-311.

28. Mari A, Rasi C, Palazzo P, Scala E: Allergen databases: current status and perspectives. Curr Allergy Asthma Rep 2009, 9:376-383.

29. Turi GJ, Ellis R, Wattie JN, Labiris NR, Inman MD: The effects of inhaled house dust mite on airway barrier function and sensitivity to inhaled methacholine in mice. Am J Physiol Lung Cell Mol Physiol 2011, 300 L185-190.

30. Hammad H, Chieppa M, Perros F, Willart MA, Germain RN, Lambrecht BN: House dust mite allergen induces asthma via Toll-like receptor 4 triggering of airway structural cells. Nat Med 2009, 15:410-416

31. Hongjia L, Qingling G, Meiying L, Weixuan W, Lihong Z, Yongsheng G, Yanli L, Jinxiang W, Liang D: House dust mite regulate the lung inflammation of asthmatic mice through TLR4 pathway in airway epithelial cells. Cell Biochem Funct 2010, 28:597-603.

32. Osterlund C, Gronlund H, Polovic N, Sundstrom S, Gafvelin G, Bucht A: The non-proteolytic house dust mite allergen Der $\mathrm{p} 2$ induce NF-kappaB and MAPK dependent activation of bronchial epithelial cells. Clin Exp Allergy 2009, 39:1199-1208.

33. Gangl K, Reininger R, Bernhard D, Campana R, Pree I, Reisinger J, Kneidinger M, Kundi M, Dolznig H, Thurnher D, Valent P, Chen KW, Vrtala S, Spitzauer S, Valenta R, Niederberger V: Cigarette smoke facilitates allergen penetration across respiratory epithelium. Allergy 2009, 64:398-405.

34. Huang YJ, Nelson CE, Brodie EL, Desantis TZ, Baek MS, Liu J, Woyke T, Allgaier M, Bristow J, Wiener-Kronish JP, Sutherland ER, King TS, Litovic N Martin RJ, Calhoun WJ, Castro M, Denlinger LC, Dimango E, Kraft M, Peters SP, Wasserman SI, Wechsler ME, Boushey HA, Lynch SV: Airway microbiota and bronchial hyperresponsiveness in patients with suboptimally controlled asthma. J Allergy Clin Immunol 2011, 127:372-381, e371-373.

35. Lee YK, Mazmanian SK: Has the microbiota played a critical role in the evolution of the adaptive immune system? Science 2010, 330:1768-1773.

36. Round JL, O'Connell RM, Mazmanian SK: Coordination of tolerogenic immune responses by the commensal microbiota. J Autoimmun 2010, 34: J220-225.

37. Bousquet J, Bieber T, Fokkens W, Kowalski M, Humbert M, Niggemann B, Simon HU, Cruz AA, Haahtela T: In Allergy, 'A new day has begun'. Allergy 2008, 63:631-633.

38. Okada H, Kuhn C, Feillet $\mathrm{H}$, Bach JF: The 'hygiene hypothesis' for autoimmune and allergic diseases: an update. Clin Exp Immunol 2010, 160:1-9.

39. Huffnagle GB: The microbiota and allergies/asthma. PLoS Pathog 2010, 6 : e1000549.

40. Hsiao WW, Fraser-Liggett CM: Human Microbiome Project-paving the way to a better understanding of ourselves and our microbes. Drug Discov Today 2009, 14:331-333.

41. Peterson J, Garges S, Giovanni M, McInnes P, Wang L, Schloss JA, Bonazzi V, McEwen JE, Wetterstrand KA, Deal C, Baker CC, Di Francesco V, Howcroft TK, Karp RW, Lunsford RD, Wellington CR, Belachew T, Wright M Giblin C, David H, Mills M, Salomon R, Mullins C, Akolkar B, Begg L, Davis C, Grandison L, Humble M, Khalsa J, Little AR, et al: The NIH Human Microbiome Project. Genome Res 2009, 19:2317-2323.

42. Schleh C, Erpenbeck VJ, Winkler C, Lauenstein HD, Nassimi M, Braun A, Krug N, Hohlfeld JM: Allergen particle binding by human primary bronchial epithelial cells is modulated by surfactant protein D. Respir Res 2010, 11:83.

43. Röschmann K, Farhat K, König P, Suck R, Ulmer A, Petersen A: Timothy grass pollen major allergen Phl $p 1$ activates respiratory epithelial cells by a non-protease mechanism. Clin Exp Allergy 2009.
44. Blume C, Foerster S, Gilles S, Becker WM, Ring J, Behrendt H, Petersen A, Traidl-Hoffmann C: Human epithelial cells of the respiratory tract and the skin differentially internalize grass pollen allergens. J Invest Dermatol 2009, 129:1935-1944.

45. Renkonen J, Mattila P, Lehti S, Mäkinen J, Sormunen R, Tervo T, Paavonen T, Renkonen R: Birch pollen allergen Bet $v 1$ bind to and travels through conjunctival epithelium in allergic patients. Allergy 2009, 64:868-875.

46. Joenvaara S, Mattila P, Renkonen J, Makitie A, Toppila-Salmi S, Lehtonen M, Salmi P, Lehti S, Makinen J, Sormunen R, Paavonen T, Renkonen R: Caveolar transport through nasal epithelium of birch pollen allergen Bet $\mathrm{v} 1$ in allergic patients. J Allergy Clin Immunol 2009, 124:135-142, e131-121.

47. Zaas DW, Swan ZD, Brown BJ, Li G, Randell SH, Degan S, Sunday ME, Wright JR, Abraham SN: Counteracting signaling activities in lipid rafts associated with the invasion of lung epithelial cells by Pseudomonas aeruginosa. J Biol Chem 2009, 284:9955-9964.

48. Yu LC: The epithelial gatekeeper against food allergy. Pediatr Neonatol 2009, 50:247-254.

49. Hens G, Bobic S, Reekmans K, Ceuppens JL, Hellings PW: Rapid systemic uptake of allergens through the respiratory mucosa. J Allergy Clin Immunol 2007, 120:472-474.

50. Markovic-Housley Z, Degano M, Lamba D, von Roepenack-Lahaye E, Clemens S, Susani M, Ferreira F, Scheiner O, Breiteneder H: Crystal structure of a hypoallergenic isoform of the major birch pollen allergen Bet $v 1$ and its likely biological function as a plant steroid carrier. J Mol Biol 2003, 325:123-133.

51. Mogensen J, Wimmer R, Larsen J, Spangfort M, Otzen D: The major birch allergen, Bet $v 1$, shows affinity for a broad spectrum of physiological ligands. J Biol Chem 2002, 277:23684-23692.

52. Mogensen JE, Ferreras M, Wimmer R, Petersen SV, Enghild JJ, Otzen DE: The major allergen from birch tree pollen, Bet $\mathrm{v} 1$, binds and permeabilizes membranes. Biochemistry 2007, 46:3356-3365.

53. Mattila K, Renkonen R: Modelling of Bet $v 1$ binding to lipids. Scand J Immunol 2009, 70:116-124.

54. Mattila P, Renkonen J, Toppila-Salmi S, Parviainen V, Joenvaara S, AlffTuomala S, Nicorici D, Renkonen R: Time-series nasal epithelial transcriptomics during natural pollen exposure in healthy subjects and allergic patients. Allergy 2010, 65:175-183.

55. Barrias ES, Dutra JM, De Souza W, Carvalho TM: Participation of macrophage membrane rafts in Trypanosoma cruzi invasion process. Biochem Biophys Res Commun 2007, 363:828-834

56. Cantin C, Holguera J, Ferreira L, Villar E, Munoz-Barroso I: Newcastle disease virus may enter cells by caveolae-mediated endocytosis. J Gen Virol 2007, 88:559-569.

57. Damm EM, Pelkmans L: Systems biology of virus entry in mammalian cells. Cell Microbiol 2006, 8:1219-1227.

58. Kowalski MP, Dubouix-Bourandy A, Bajmoczi M, Golan DE, Zaidi T, Coutinho-Sledge YS, Gygi MP, Gygi SP, Wiemer EA, Pier GB: Host resistance to lung infection mediated by major vault protein in epithelial cells. Science 2007, 317:130-132.

59. Marsh M, Helenius A: Virus entry: open sesame. Cell 2006, 124:729-740.

60. Moriyama T, Marquez JP, Wakatsuki T, Sorokin A: Caveolar endocytosis is critical for BK virus infection of human renal proximal tubular epithelial cells. J Virol 2007, 81:8552-8562.

61. Parr RD, Storey SM, Mitchell DM, Mclntosh AL, Zhou M, Mir KD, Ball JM: The rotavirus enterotoxin NSP4 directly interacts with the caveolar structural protein caveolin-1. J Virol 2006, 80:2842-2854

62. Vroling AB, Jonker MJ, Luiten S, Breit TM, Fokkens WJ, van Drunen CM: Primary Nasal Epithelium Exposed to House Dust Mite Extract Shows Activated Expression in Allergic Individuals. Am J Respir Cell Mol Biol 2008, 38:293-299.

63. Vroling $A B$, Jonker MJ, Breit TM, Fokkens WJ, van Drunen CM: Comparison of expression profiles induced by dust mite in airway epithelia reveals a common pathway. Allergy 2008, 63:461-467.

64. van Drunen $C M$, Vroling $A B$, Rinia $A B$, Fokkens WJ: Considerations on the application of microarray analysis in rhinology. Rhinology 2008, 46:259-266.

65. Tesse R, Pandey RC, Kabesch M: Genetic variations in toll-like receptor pathway genes influence asthma and atopy. Allergy 2011, 66:307-316.

66. Ege MJ, Mayer M, Normand AC, Genuneit J, Cookson WO, BraunFahrlander C, Heederik D, Piarroux R, von Mutius E: Exposure to 
environmental microorganisms and childhood asthma. N Engl J Med 2011, 364:701-709.

67. Ege MJ, Strachan DP, Cookson WO, Moffatt MF, Gut I, Lathrop M, Kabesch M, Genuneit J, Buchele G, Sozanska B, Boznanski A, Cullinan P, Horak E, Bieli C, Braun-Fahrlander C, Heederik D, von Mutius E: Geneenvironment interaction for childhood asthma and exposure to farming in Central Europe. J Allergy Clin Immunol 2011, 127:138-144, 144 e131-134.

68. Barnes KC: An update on the genetics of atopic dermatitis: scratching the surface in 2009. J Allergy Clin Immunol 2010, 125:16-29, e11-11; quiz 30-11.

69. Holloway JW, Yang IA, Holgate ST: Genetics of allergic disease. J Allergy Clin Immunol 2010, 125:S81-94.

70. Weidinger $\mathrm{S}$, O'Sullivan M, Illig T, Baurecht H, Depner M, Rodriguez E, Ruether A, Klopp N, Vogelberg C, Weiland SK, McLean WH, von Mutius E, Irvine $A D$, Kabesch M: Filaggrin mutations, atopic eczema, hay fever, and asthma in children. J Allergy Clin Immunol 2008, 121:1203-1209, e1201.

71. Busse $\mathrm{WW}$, Lemanske RF Jr, Gern JE: Role of viral respiratory infections in asthma and asthma exacerbations. Lancet 2010, 376:826-834.

72. Papadopoulos NG, Christodoulou I, Rohde G, Agache I, Almqvist C, Bruno A, Bonini S, Bont L, Bossios A, Bousquet J, Braido F, Brusselle G, Canonica GW, Carlsen KH, Chanez P, Fokkens WJ, Garcia-Garcia M, Gjomarkaj M, Haahtela T, Holgate ST, Johnston SL, Konstantinou G, Kowalski M, Lewandowska-Polak A, Lodrup-Carlsen K, Makela M, Malkusova I, Mullol J, Nieto $A$, Eller $E$, et al: Viruses and bacteria in acute asthma exacerbations - A GA(2) LEN-DARE* systematic review. Allergy 2010.

73. Swarr DT, Hakonarson $\mathrm{H}$ : Unraveling the complex genetic underpinnings of asthma and allergic disorders. Curr Opin Allergy Clin Immunol 2010, 10:434-442.

74. Wang H, Chavali S, Mobini R, Muraro A, Barbon F, Boldrin D, Aberg N, Benson M: A pathway-based approach to find novel markers of local glucocorticoid treatment in intermittent allergic rhinitis. Allergy 2011, 66:132-140

75. Broccardo CJ, Mahaffey S, Schwarz J, Wruck L, David G, Schlievert PM, Reisdorph NA, Leung DY: Comparative proteomic profiling of patients with atopic dermatitis based on history of eczema herpeticum infection and Staphylococcus aureus colonization. J Allergy Clin Immunol 2011, 127:186-193, 193 e181-111.

76. Sampaio JL, Gerl MJ, Klose C, Ejsing CS, Beug H, Simons K, Shevchenko A: Membrane lipidome of an epithelial cell line. Proc Natl Acad Sci USA 2011, 108:1903-1907.

doi:10.1186/2045-7022-1-5

Cite this article as: Mattila et al:: Allergy as an epithelial barrier disease.

Clinical and Translational Allergy 2011 1:5.

\section{Submit your next manuscript to BioMed Central and take full advantage of:}

- Convenient online submission

- Thorough peer review

- No space constraints or color figure charges

- Immediate publication on acceptance

- Inclusion in PubMed, CAS, Scopus and Google Scholar

- Research which is freely available for redistribution

Submit your manuscript at www.biomedcentral.com/submit 